\title{
Does Entrepreneurial Leadership Matter for Micro-Enterprise Development?: Lesson from West Java in Indonesia*
}

\author{
Ellen RUSLIATI ${ }^{1}$, Mulyaningrum MULYANINGRUM ${ }^{2}$, Agus WIBOWO ${ }^{3}$, Bagus Shandy NARMADITYA ${ }^{4}$
}

Received: June 02, 2020 Revised: June 28, 2020 Accepted: July 09, 2020

\begin{abstract}
This research investigates the role of entrepreneurial leadership in micro-enterprise development in the district of Majalengka in West Java, Indonesia. This study applied a qualitative content analysis method to understand the phenomenon of micro-enterprises comprehensively. The data of this research was collected using surveys, interviews, and a group discussion. The findings indicated that technological information adaptation plays a crucial role in the development of micro-enterprise development. Since the group of millennials dominated the leadership, it has provided more creativity by implementing technological information instead of the previous generation that faced difficulties in adopting the technology. This study noted that inadequate technology adaptation makes micro-business gradually lose customers, and the business was threatened to close. Meanwhile, the role of leadership drives the business development, sales have risen, the number of products has been increasingly diverse, and business capital and number of employees have grown. The establishment of an entrepreneur group could facilitate peer-to-peer contact, knowledge transfer, training, and intervention to enhance leadership and business development. This finding pointed out that the leadership will successfully influence business development when supported by several characteristics such as manage the business, capture opportunities, confidence, firmness, personal integrity, communication, and social and technical expertise.
\end{abstract}

Keywords: Entrepreneurial Leadership, Business Development, Micro Enterprise, SMEs

JEL Classification Code: D10, L26, P13

\section{Introduction}

The balance of trade in Indonesia has fluctuated in the last decade. In 2018, Indonesia's trade balance showed a deficit

\footnotetext{
*Acknowledgements:

We are grateful to anonymous referees and editor of the journal for their valuable comments and suggestions an attempt to enhance the quality of article.

${ }^{1}$ First Author and Corresponding Author. Faculty of Economics and Business, Universitas Pasundan, Indonesia [Postal Address: JI.

Taman Sari No. 6-8, Bandung, Jawa Barat, 40116, Indonesia] Email: ellenrusliati44@gmail.com

${ }^{2}$ Faculty of Economics and Business, Universitas Pasundan, Indonesia. Email: mulyaningrum.unpas@gmail.com

${ }^{3}$ Faculty of Economics, Universitas Negeri Jakarta, Indonesia. Email: agus-wibowo@unj.ac.id

${ }^{4}$ Faculty of Economics, Universitas Negeri Malang, Indonesia.

Email: bagus.shandy.fe@um.ac.id

(c) Copyright: The Author(s)

This is an Open Access article distributed under the terms of the Creative Commons Attribution Non-Commercial License (http://Creativecommons.org/licenses/by-nc/4.0/) which permits unrestricted noncommercial use, distribution, and reproduction in any medium, provided the original work is properly cited.
}

of USD8.57 billion. However, in the previous year, there was a surplus of approximately USD11.8 billion. Indonesia had experienced a deficit for three years in a row from 2012 to 2014 (BPS, 2019). The goods imported included machinery or mechanical aircraft $(17.12 \%$ of the total imports), iron and steel $(6.45 \%)$, cereal $(2.39 \%)$, fruits $(0.83 \%)$, and vegetables $(0.46 \%)$. The entry of various foreign products into Indonesia put heavy pressure on micro-enterprises. Micro-enterprises with locally-based products, agricultural, and plantation products, are expected to reduce the number of these three types of imported products. Therefore, innovation is needed to significantly increase employment, social stability, and economic prosperity of the country (Sohn, 2017; Harrison et al., 2014).

The modern business environment is characterized by global markets, competition, technology, and innovation (Linton \& Solomon, 2017; Ha \& Nguyen, 2020). For this matter, micro-enterprises need to find and implement strategies that enable them to face existing challenges (Sanyal et al., 2020). The role of the leader is needed to provide better quality products at lower costs and to use appropriate strategies (Daka et al., 2017; Zainol et al., 2018). 
Effective leadership is an integral part of an organization to survive in business to be able to deal with various problems that arise as a result of rapid economic changes. A leader is someone who controls and is responsible for the operation of an organization. Besides, a good leader is capable of setting optimistic goals and objectives and controlling the company's operations to achieve them using effective strategies. Moreover, good leaders can influence and motivate organizational members to strengthen the organization's positive culture through the utilization of their potential and affect employee performance and productivity (Andersen et al., 2018; Setyawati et al., 2019).

Several previous studies found a robust correlation between leadership and business performance (Aziz et al., 2013; Paudel, 2019; Akram et al., 2019). Additionally, Van Wart (2012) remarked that leadership varies due to non-strategic factors such as intelligence, self-confidence, decisiveness, energy, personal integrity, communication skills, social skills, and technical skills. In SMEs, leaders play a vital role in encouraging and supporting individual employees' initiatives and improving work procedures for the benefit of the organization (Hease \& Franco, 2020; Simba \& Thai, 2019). Entrepreneurial leadership relies on creating new products and processes, developing expansion opportunities in the existing business, working in social institutions and dealing with ignored social issues, participating in social and political movements, and contributing to the change of current services and policies implemented by civil society organization and governments (Esmer et al., 2018).

The district of Majalengka is an agricultural area in which the majority of the population has a livelihood as farmers. Derivative products from agriculture, plantations, livestock, and fisheries that have been successfully developed are made from cassava, sweet potato, sticky rice, guava, soursop, pumpkin, mango, and fish. Local agricultural products have successfully fulfilled the utilization of agricultural products for the Majalengka community's consumption. A preliminary study by Rusliati et al. (2018) showed that the right strategy for micro and small enterprises in Majalengka was market penetration and new product development. Market penetration is the process of offering existing products to the markets in different ways, while the development of new products refers to offering new products to the markets. For this reason, this present study comprehensively attempts to understand the role of leadership in driving micro-enterprises development.

\section{Literature Review}

Small- and medium-sized enterprises (SMEs) are considered as the source of a country's primary economic support for creating job opportunities (Suparno et al., 2020; Madanchian et al., 2016; Belas et al., 2018). SMEs are also viewed as the engine of growth and catalysts for economic and social transformation in a country. However, maintaining small- and medium-sized enterprises faces some problems: the lack of working capital, low-qualified human resources, and the lack of control of science and technology (Bose \& Roy, 2017; Kostini \& Raharja, 2020). These problems occur because the micro-enterprise is considered as income generating, which focuses more on increasing income. It is characterized more as a family-owned business, using ordinary and simple technology, lacking capital access, and lacking a separation between venture capital and individual needs.

These complex problems require the presence of a leader who asserts his position in the middle of an economic changing environment and has the spirit of entrepreneurship. In the current business environment, besides factors such as finance, strategy, and innovation, it becomes essential to find out about the leader of small and micro-enterprises, due to the increasing need to understand the road to success and the process of creating sustainable competitive advantage (Madanchian et al., 2016). Bass (1985) introduces three types of leadership styles: transactional, transformational, and passive-avoidant leaders. Transactional leaders are leaders who guide and motivate their followers in the direction of established goals by clarifying role and task requirements. Transactional leadership is created based on the exchange between leaders and followers. On the other hand, transformational leadership can lead to the highperforming organization due to the supportive, delegative, participative, collaborative leader-follower relationship that evolves in an organization. Lastly, passive-avoidant leadership, which basically is inactive, is often referred to as a lack of leadership (Nguyen et al., 2017; Afsar et al., 2017).

Some literature believes that leadership style is closely linked with business performance. For instance, Aziz et al. (2013) showed a positive relationship between transactional, transformational leadership, and business performance. However, passive-avoidant leadership was negatively correlated with business performance. Additionally, Taylor (2017) stated that transformational and transactional leadership styles should be implemented complementarily to be able to achieve organizational objectives. Entrepreneurial leadership has three main characters: (1) specific charisma as the basis to create a trust of the followers, (2) specific concern to the individual in order to be able to be empathic to the followers, (3) specific alacrity to find out the solution rationally, not emotionally. Soekarso and Iskandar (2015) stated that the leader has to own two main characteristics to make the community runs effectively: (1) as a problem solver, that relates to determining job description, giving advice, solution, information, and opinion; (2) as a group or social caretaker, that relates to helping the group or organization in order to run better and more effective, sending and receiving agreement with other communities, and many other things. 


\section{Research Methods and Materials}

This study applied a qualitative content analysis method to comprehensively understand the phenomenon of microenterprises in the district Majalengka of West Java in Indonesia, as well as entrepreneurial leadership, direction, and motivation in line with rural economic development. The study in the district of Majalengka is unique due to an agricultural area in which the majority of the population has a livelihood as farmers that need to have market penetration and new product development. Data was obtained by direct observation of micro-enterprise leadership in the rural area, studying rural documents as secondary data, personal interviews with key rural stakeholders, and group discussions with influential business groups (see Table 1). Furthermore, focus group discussions were also carried out with representatives of each group of entrepreneurs and rural institutions in an effort to cross-check information obtained from previous data collection steps. The surveys and interviews were conducted with micro-entrepreneurs in the district of Majalengka from 2017 to 2019.

\section{Results and Discussion}

\subsection{Leadership and Business Development}

The results of this study showed some differences in leadership styles between millennials and older generations. Millennials' generation, aged between 21 and 37 years, are more likely understand the global changes and the market. Also, they create groups of entrepreneurs as a means of learning, sharing knowledge and experience, exploring new product/process ideas, as well as establishing business relationships (Sujianto et al., 2020). Meanwhile, the previous generation (Generation X) leadership tends to maintain traditional production processes, product types, and marketing. Generation X can adjust to global changes with the support of their children who belong to the millennial generation. They also can join the business groups so that personal contact, knowledge transfer, training, and intervention will be enhanced. The large number of micro-enterprises will expand employment opportunities and encourage economic growth and distribution, which ultimately impacts people's welfare (Dahliah et al., 2020). Micro-entrepreneurs hold workers from relatives, friends, and neighbors. Moreover, giving that life expectancy of others was to be worshipped, so they were always eager to develop their business. Salaries or wages given to workers were accompanied by prayer so that the business could grow.

The findings showed that the strategy of increasing sales, marketing areas, product diversity, and the amount of capital had been implemented, which indicated the success of the business of micro-entrepreneurs in Majalengka. The awareness of the importance of maintaining product quality; registering the product to obtain home food industry regulation and halal certification; using online media to promote and expand the network and find ideas; using groups as a means of learning, comparative studies, various experiences, and networking, were determined by the ability of leaders to develop their businesses and adapt to the environment.

The business development can be seen using the balanced scorecard approach, which included four perspectives,

Table 1: The demographic of respondent

\begin{tabular}{|c|l|l|c|}
\hline No & \multicolumn{1}{|c|}{ Demographic } & Categories & Percentage \\
\hline 1 & Gender & Male & $53 \%$ \\
& & Female & $47 \%$ \\
\hline 2 & Age & 20 and under & $0 \%$ \\
& & $21-37=36 \%$ & $36 \%$ \\
\hline 3 & Education & 37 and above & $64 \%$ \\
\hline & & High School & $86 \%$ \\
& & Diploma & $0 \%$ \\
\hline 4 & Business sector & Bachelor degree & $14 \%$ \\
& & Master degree & $0 \%$ \\
\hline 5 & & Food & $77 \%$ \\
& & Manufacture & $18 \%$ \\
\hline 6 & Turnover & Service & $5 \%$ \\
\hline & & 4 year and under & $35 \%$ \\
& & 5 year and above & $65 \%$ \\
\hline
\end{tabular}


namely, (1) financial perspective and total sales and capital, (2) marketing perspective and area of marketing, (3) process perspective and product diversity, and (4) human resource perspective and improvement number of employees. Based on these four perspectives, micro-entrepreneurs in the district of Majalengka only succeeded in increasing the area of marketing. Marketing at the initial stage was only conducted in the surrounding environment. However, with the development of information technology, the millennial generation also conducted marketing through social media, Facebook, and Instagram. Furthermore, the Majalengka Young Entrepreneurs Forum and Saung Suung Yuceu, in collaboration with the cooperative and SMEs ministry, opened outlets in several locations to sell products.

Micro-enterprise development was largely determined by the ability of leaders to work hard and be smart to come up with new ideas in producing and marketing products. The marketing and production perspective were the focus of the attention of business owners in Majalengka. The assurance that the product can be marketed was the driving force for running the business. Furthermore, product innovation was carried out through group discussions, comparative studies with competing products, Internet search, and modification according to their abilities and creativity. The financial perspective had not been well measured. It was found that simple records had been kept, however, it could not be presented in the form of formal financial reports.

Startup entrepreneurs have shortcomings, are inexperienced, but have the opportunity to mitigate their shortcomings by learning from other entrepreneurs' experiences and through business studies. The ability to utilize information technology and join groups of entrepreneurs enable them to learn, gain insight, and enhance their experience. Micro-enterprise leaders in Majalengka should have the ability to seize opportunities. Also, they should have confidence, enthusiasm, firmness, personal integrity, and social and technical communication skills (Van Wart, 2012). Leaders' leadership style will influence the business performance; passive leaders have a negative influence on their business (Aziz et al., 2013). Leaders should determine the direction of their business in the future through the formulation, implementation, and evaluation of strategies (Do et al., 2020). This is in accordance with the results of the research by (Nanjundeswaras \& Swamy, 2014), which stated that leaders contributed significantly to improving the business.

\subsection{Market Penetration and New Product Development}

Market penetration strategies were carried out by keeping producing good quality products with the aim of
(1) maintaining market share, (2) dominating market growth, (3) eliminating competitors, and (4) increasing customer use (Rusliati et al., 2018). Business leaders always strived to produce good quality products and better packaging by including brands, PIRT numbers, halal labels, expiration dates, ingredients (for food products), and typical products of Majalengka. The promotion was conducted both offline and online. In addition, they also joined Majalengka Mart, Majalengka Young Entrepreneurs Forum, Saung Suung Yuceu, and Majalengka Advanced Community. Business leaders also accessed the Majalengka District Government to facilitate SME products in BIJB, so that they could have outlets complete with bus parking facilities in the Cipali rest area (Esmer et al., 2018). However, online sales were being explored by business leaders from the millennial group.

New product development strategies include (1) research and development, (2) customer needs assessment, and (3) brand clarity (Rusliati et al., 2018). The efforts to be made by leaders are actively searching for new ideas from competitors, and tracing the interests or tastes of consumers through the use of the Internet. The search for regional potential was always done by exploring the culture of each village. The findings showed that the peculiarities of each village in the district of Majalengka were in accordance with the characteristics of highland locations cultivating plantation areas, hilly terrain, and lowlands. The inclusion of Majalengka's production brands was spread on a variety of products ranging from food and beverages to batik to footwear.

The development of information technology helps a micro-entrepreneur to obtain information from the use of smartphones, such as finding the product requested by the consumer or finding the product offered by the competitors, including determining price, promotion and distribution. Micro-enterprises in the district of Majalengka, especially from the millennial generation, had successfully taken advantage of information technology to observe environmental factors so they could adapt well to the economic changes. These skills are shared with the other organizations, especially to non-millennial generation, who is well experienced. Therefore, there is more synergy between them. This synergy between micro-enterprises is conducted in the hope of strengthening contribution to the economy.

These findings support a previous study by Taylor (2017), which stated that transactional and transformational leadership could be applied together to increase organizational performance. A leader cannot act passively in running its business because it can lead to the loss of customers (for starter) and financial crisis and bankruptcy (Tayal et al., 2018). Recently, the relevant benefit offered to the member is the implementation of a digital program (Rusliati, 2018), 
including individual contact, knowledge transfer, training and workshop, and intervention. This digital program can be influenced by organization, person, innovation, development of information technology, government's support, and role, and consumer's hope. These can lead to a result of the increase of micro-enterprise performance in the digital economy, such as the usage of broadband Internet, mobile Internet users, mobile Internet access traffic, e-commerce transaction, online retail sales as part of total retail sales.

The characteristics of entrepreneurial leadership are as follows: (1) Motivational. Entrepreneurial leaders not only direct others to work properly, but also motivate others so that the work done is excellent; (2) Achievement-oriented. Entrepreneurial leaders are timely, skilled, productive, and competent in building a business or businesses; (3) Persistent. An entrepreneurial leader is a person who is persistent in fighting for his dreams, his determination, is tenacious, and does not easily give up when he fails; (4) Risk-taker. Entrepreneurial leadership dares to take risks, not afraid to try to do something. He did it only based on instinct or instinct alone, but everything has been considered and planned well in advance; and (5) Visionary. An entrepreneurial leader can predict the future of his business, so he has confidence and can convince others to achieve these goals jointly.

Change is something that is bound to happen, especially with the development of information technology, resulting in information developing rapidly. Leaders work with available data, including analysis of internal and external factors and competitor analysis. Anticipating changes early requires the ability of leaders to see changes, both from external factors (scientific, political, social, economic, consumer tastes, shopping habits, and all factors that cannot be controlled by the company) or internal factors (HR, finance, marketing, information systems, operating processes, and all factors that can be controlled by the company). In addition, changes made by competitors, like ways of promotion, products produced, ways of service, and all aspects of competitors.

Leaders' ability to continually see changes that occur in external, internal factors and competitors becomes valuable information for formulating strategies. The formulation of the strategy should be followed by the implementation of the strategy, which shows what programs must be carried out based on the formulation of the strategy to achieve the targets set. The leader has the authority and responsibility to motivate, be a charismatic figure, and directing his subordinates to implement the program and determine the targets to be achieved. The formulation of strategy requires organizational change, meaning that it adapts and becomes more empowered to sustain the business. Ideally, changes are made when companies are at a growth stage; however, change is not pleasant to do, because bringing organizational members into the area is uncomfortable, so change is often rejected. This rejection can be understood because the change is not necessarily successful. However, if it is not done, then it will bring the company to a lower level of performance, and eventually, the sales level will slow down and eventually disappear. Strategy implementation is an activity that is more difficult than strategy formulation because it involves all members of the company. Leaders also play a role in solving problems in implementing the strategy.

\section{Conclusions}

The conclusions arrived at from the results of this research are: first, the entrepreneurial leadership of microentrepreneurs in Majalengka, which includes millennials who have open access to change, a desire to succeed in business, are open to broad relationships, and have a straightforward nature of cooperation. Therefore, they are happy to join business groups to participate in digital programs, namely, personal contact, knowledge transfer, training, and intervention. The leadership of entrepreneurs from Generation X needs support from children or the environment to be willing to make changes. Second, business development has increased sales, broader marketing area, increased capital, and a more significant number of employees, even though they are in a limited amount because millennial generation entrepreneurs are still at the introduction stage in business. Third, leadership will influence business development, if it is supported by the ability to manage the business, capture opportunities, confidence, firmness, personal integrity, communication, social and technical expertise, and courage to take risks.

\section{References}

Afsar, B., Badir, Y. F., Saeed, B. B., \& Hafeez, S. (2017). Transformational and transactional leadership and employee's entrepreneurial behavior in knowledge-intensive industries. The International Journal of Human Resource Management, 28(2), 307-332.

Akram, M. U., Chauhan, C., Ghosh, K., \& Singh, A. (2019). Knowledge Management, Sustainable Business Performance and Empowering Leadership: A FirmLevel Approach. International Journal of Knowledge Management, 15(2), 20-35.

Andersen, L. B., Bjørnholt, B., Bro, L. L., \& Holm-Petersen, C. (2018). Leadership and motivation: A qualitative study of transformational leadership and public service motivation. International Review of Administrative Sciences, 84(4), 675-691.

Aziz, R.A., Abdullah, M.H., Tajudin, A., Mahmood, R. (2013). The Effect of Leadership Styles on the Business Performance of SMEs in Malaysia. International Journal of Economics, Business and Management Studies. 2, 45-52.

Bass, B. M. (1985). Leadership and Performance beyond Expectations. New York, NY: Free Press. 
Belas, J., Smrcka, L., Gavurova, B., \& Dvorsky, J. (2018). The impact of Social and Economic Factors in the Credit Risk Management of SME. Technological and Economic Development of Economy, 24(3), 1215-1230.

Bose, T. K., \& Roy, R. (2017). Financing Sources and Problems of SMEs in Developing Countries: A Study based on Khulna Region of Bangladesh. Journal of Entrepreneurship and Management, 6(1), 12-22.

Daka, A., Sandada, M., \& Mbasera, M. (2017). The Role of Leadership Skills, Innovation, Legal Factors and Marketing Skills in the Growth of SMEs in Zimbabwe. Journal of Business, 1(1), 61-72.

Dahliah, D., Kurniawan, A., \& Putra, A. H. P. K. (2020). Analysis and Strategy of Economic Development Policy for SMEs in Indonesia. Journal of Asian Finance, Economics, and Business, 7(5), 103-110. https://doi.org/10.13106/jafeb.2020.vol7. no5.103

Do, D. T., Nguyen, T. H., Nguyen, T. H. N., Ha, H. H., \& Le, T. T. (2020). The Influence of Leadership Style on Accountants' Commitment with Enterprise: An Empirical Study on Vietnamese FDI Firms. Journal of Asian Finance, Economics, and Business, 7(3), 235-243. https://doi.org/10.13106/ jafeb.2020.vol7.no3.235

Esmer, Y., Ulusoy, T., \& Dayi, F. (2018). Innovation in Participation Banks: A Review on Turkey. In Conference: 2nd International Scientific Conference: Economics and Management, (pp. 115127).

Ha, H. H., \& Nguyen, A. H. (2020). Determinants of Voluntary Audit of Small and Medium Sized Enterprises: Evidence from Vietnam. Journal of Asian Finance, Economics, and Business, 7(5), 41-50. https://doi.org/10.13106/jafeb.2020.vol7.no5.041

Haase, H., \& Franco, M. (2020). Leadership and collective entrepreneurship: evidence from the health care sector. Innovation: The European Journal of Social Science Research, 1-18. https://doi.org/10.1080/13511610.2020.17562 31

Harrison, R., Jaumandreu, J., Mairesse, J., \& Peters, B. (2014). Does Innovation Stimulate Employment? A Firm-level Analysis Using Comparable Micro-data from Four European Countries. International Journal of Industrial Organization, 35 , 29-43.

Kostini, N., \& Raharja, S. (2020). Analysis of Financial Behavior of SMEs in the Creative Industries in Bandung City, Indonesia. Review of Integrative Business and Economics Research, 9(1), 131-139.

Linton, J. D., \& Solomon, G. T. (2017). Technology, Innovation, Entrepreneurship and the Small Business-Technology and Innovation in Small Business. Journal of Small Business Management, 55(2), 196-199.

Madanchian, M., \& Taherdoost, H. (2017). Role of leadership in small and medium enterprises (SMEs). Journal of Economics and Management Systems, 2, 240-243.
Nguyen, T. T., Mia, L., Winata, L., \& Chong, V. K. (2017). Effect of transformational-leadership style and management control system on managerial performance. Journal of Business Research, 70, 202-213.

Paudel, S. (2019). Entrepreneurial Leadership and Business Performance. South Asian Journal of Business Studies, 8(3), 348-369

Rusliati, E., Mulyaningrum., \& Sufyani, M. (2018). Development Strategies of Micro Business in Majalengka Regency. Trikonomika 17, 101-108.

Sanyal, S., Hisam, M. W., \& Baawain, A. M. S. (2020). Challenges Facing Internationalization of SMEs in Emerging Economies: A Study on OECD Model. Journal of Asian Finance, Economics, and Business, 7(2), 281-289. https://doi.org/10.13106/ jafeb.2020.vol7.no2.281

Setiawati, I., Ratnasari, S. L., \& Hakim, L. (2019). The Effects of Organizational Culture, Leadership Style, Motivation, and Organizational Commitment on Employee Work Discipline at Pancaran Maitri Foundation. Management Research Spectrum, 9(1), 42-47.

Simba, A., \& Thai, M. T. T. (2019). Advancing Entrepreneurial Leadership as a Practice in MSME Management and Development. Journal of Small Business Management, 57(2), 397-416.

Soekarsa., \& Iskandar P. (2015). Leadership: Theory and Practice. Penerbit Erlangga. Jakarta.

Sohn, K. (2017). The risk preferences of entrepreneurs in Indonesia. Bulletin of Economic Research, 69(3), 271-287.

Sujianto, E. A., Astutiningsih, S. E., Aisyah, B. N., Aswad, M., Estiningrum, S. D., \& Narmaditya, B. S. (2020). Cooperative Entrepreneurial Decisions: Do Educational, Environment, and Family Aspects Matters?. International Journal of Psychosocial Rehabilitation, 24(6), 166-173.

Suparno., Wibowo, A., Mukhtar, S., Narmaditya, B. S., \& Sinta, H. D. (2019). The Determinant Factors of Development Batik Cluster Business: Lesson from Pekalongan, Indonesia. Journal of Asian Finance, Economics and Business, 6(4), 227-233. https://doi.org/10.13106/jafeb.2019.vol6.no4.227

Tayal, R., Upadhya, R. K., Yadav, M., Rangnekar, S., \& Singh, R. (2018). The impact of transformational leadership on employees' acceptance to change. VINE Journal of Information and Knowledge Management Systems, 48(4), 559-578

Taylor, J. (2017). Management of Australian water utilities: The significance of transactional and transformational leadership. Australian Journal of Public Administration, 76(1), 18-32.

Van Wart, M. (2012). Leadership in Public Organization, an Introduction ( $2^{\text {nd }}$ ed.). New York, NY: M.E. Sharpe Inc.

Zainol, F. A., Daud, W. N. W., Shamsu, L., Abubakar, H. S., \& Halim, H. A. (2018). A linkage between entrepreneurial leadership and SMEs performance: An integrated review. International Journal of Academic Research in Business and Social Sciences, 8(4), 104-118. 